\title{
Idiopathic Pulmonary Fibrosis-Clinical presentation, outcome and baseline prognostic factors in a Portuguese cohort ${ }^{\text {th }}$
}

\author{
F. Soares Pires ${ }^{a, *}$, P. Caetano Mota ${ }^{a}$, N. Melo ${ }^{a}$, D. Costa ${ }^{b, c}$, J.M. Jesus ${ }^{d}$, R. Cunha ${ }^{d}$, \\ S. Guimarães ${ }^{e}$, C. Souto-Moura ${ }^{e, f}, A$. Morais ${ }^{a, f}$ \\ a Serviço de Pneumologia, Centro Hospitalar de São João, Porto, Portugal \\ b Departamento de Epidemiologia Clínica, Medicina Preditiva e Saúde Pública da Faculdade de Medicina da Universidade do \\ Porto, Porto, Portugal \\ c Instituto de Saúde Pública da Universidade do Porto, Porto, Portugal \\ d Serviço de Radiologia, Centro Hospitalar de São João, Porto, Portugal \\ e Serviço de Anatomia Patológica, Centro Hospitalar de São João, Porto, Portugal \\ ${ }^{f}$ Faculdade de Medicina da Universidade do Porto, Porto, Portugal
}

Received 19 September 2011; accepted 2 May 2012

\section{KEYWORDS}

Idiopathic Pulmonary Fibrosis;

Survival;

Prognosis

\begin{abstract}
Introduction: Idiopathic Pulmonary Fibrosis (IPF) is the most common disease in the subgroup of idiopathic interstitial pneumonias. It is inevitably associated to a bad prognosis, although assuming a highly variable clinical course.

Methods: Patients with IPF, observed at Interstitial Lung Diseases outpatient clinic of Centro Hospitalar de São João - Porto, Portugal, were identified and clinical, functional, radiological and bronchoalveolar lavage (BAL) parameters were reviewed. Their clinical course and survival were analyzed in order to identify prognostic factors.

Results: Eighty-one patients were included, with a mean age at diagnosis of 63.8 years old. At diagnosis, the main functional abnormalities were restrictive physiology, reduced lung diffusion

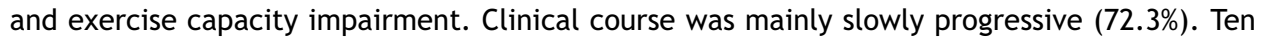
patients (13.2\%) had a rapid progression and $11(14.5 \%)$ patients had an acute exacerbation during the course of the disease. IPF's rapid progression was associated to a higher functional impairment at diagnosis, namely in what is related with Functional Vital Capacity (FVC) and Total Lung Capacity (TLC). Median survival was 36 months. A significant difference in survival was observed among different types of clinical course -41 months for slow progressors and 9 months for rapid progressors. Lower levels of FVC, TLC, six-minute walk test (6MWT) distance and
\end{abstract}

\footnotetext{
放 Please cite this article as: Pires FS, et al., Fibrose Pulmonar Idiopática - Apresentação clínica, evolução e factores prognósticos basais numa coorte portuguesa. Rev Port Pneumol. 2010. http://dx.doi.org/10.1016/j.rppneu.2012.05.002.

* Corresponding author.

E-mail address: filipasp@gmail.com (F. Soares Pires).
}

2173-5115/\$ - see front matter @ 2011 Sociedade Portuguesa de Pneumologia. Published by Elsevier España, S.L. All rights reserved. 


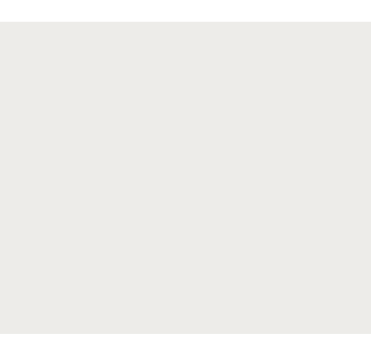

\section{PALAVRAS-CHAVE}

Fibrose Pulmonar

Idiopática;

Sobrevivência;

Prognóstico rest $\mathrm{PaO}_{2}$, and higher $\mathrm{BAL}$ neutrophil count were associated with poorer survival in univariate analysis.

Conclusion: The analysis of this group of IPF patients confirms two clearly different phenotypes, slow and rapid progressors. Those phenotypes seem to have different presentations and a remarkably different natural history. These results could mean different physiopathologic pathways, which could implicate different therapeutic approaches.

(c) 2011 Sociedade Portuguesa de Pneumologia. Published by Elsevier España, S.L. All rights reserved.

Fibrose Pulmonar Idiopática - Apresentação clínica, evolução e factores prognósticos basais numa coorte portuguesa

\section{Resumo}

Introdução: A Fibrose Pulmonar Idiopática (FPI) é a patologia mais comum no subgrupo das Pneumonias Intersticiais Idiopáticas. Apesar de uma grande variabilidade no tipo de evolução clínica, está inexoravelmente associada a um mau prognóstico.

Material e métodos: Foram identificados doentes com FPI, observados na consulta de Doenças Pulmonares Difusas do Centro Hospitalar de São João, Porto, e revistos os seus parâmetros clínicos, funcionais, radiológicos e do lavado broncoalveolar (LBA). A evolução clínica e sobrevivência foram avaliadas, tendo sido igualmente identificados factores prognósticos.

Resultados: Foram incluídos 81 doentes com uma média de idade de 63.8 anos. Na altura do diagnóstico, as principais alterações funcionais identificadas foram restrição, redução da difusão pulmonar e da capacidade de exercício. A maioria dos doentes (72.3\%) apresentou uma evolução clínica lentamente progressiva. Em 10 doentes (13.2\%), foi observada uma evolução rapidamente progressiva e 11 (14.5\%) apresentaram exacerbação aguda. Verificouse uma associação entre a evolução rapidamente progressiva e uma maior gravidade funcional ao diagnóstico, nomeadamente na Capacidade Vital Forçada (CVF) e Capacidade Pulmonar Total (CPT). A sobrevivência mediana foi de 36 meses. Verificou-se uma diferença estatisticamente significativa na sobrevivência entre os diferentes grupos de evolução clínica - 41 meses para os doentes com evolução lentamente progressiva e 9 meses para os doentes com evolução rapidamente progressiva. Valores inferiores de CVF, CPT, distância na Prova da marcha dos 6 minutos e $\mathrm{PaO} 2$ em repouso, bem como o maior grau de neutrofilia no LBA estiveram associados a uma sobrevivência inferior em análise univariada.

Conclusão: A análise deste grupo de doentes com FPI confirma a existência de 2 fenótipos claramente distintos, o de evolução lenta e o de evolução rapidamente progressiva. Estes fenótipos têm uma diferente apresentação clínica e uma história natural da doença claramente distinta, sugerindo a presença de diferentes mecanismos fisiopatológicos, os quais poderão implicar diferentes abordagens terapêuticas.

(c) 2011 Sociedade Portuguesa de Pneumologia. Publicado por Elsevier España, S.L. Todos os direitos reservados.

\section{Introduction}

Idiopathic Pulmonary Fibrosis (IPF) is the most common disease in the subgroup of Idiopathic Interstitial Pneumonias. ${ }^{1,2}$ It is a disease of the elderly, with presentation occurring usually in the sixth and seventh decades, more frequently in men. ${ }^{3-5}$ Both etiology and key mechanisms of pathogenesis remain to be understood. ${ }^{3}$

IPF's typical histological pattern is Usual Interstitial Pneumonia (UIP). 6 However, in the absence of biopsy, IPF can be diagnosed based on ATS/ERS criteria - a group of clinical, radiological and physiological parameters, internationally accepted and validated, in which typical signs at Chest High-Resolution Computerized Tomography (HRCT) have a prominent role. ${ }^{3,7}$
The clinical history of the disease is quite variable; there is usually a slow physiological deterioration, but in some patients there is a faster decline in lung function and death occurs within 6-12 months after diagnosis. ${ }^{8-10}$ Others experience an acute exacerbation during the course of the disease with a sudden worsening of respiratory symptoms, hypoxemia and the appearance of new radiological infiltrates without an identifiable cause. ${ }^{11,12}$

Despite different types of clinical course, IPF is inevitably associated with a poor prognosis, with a median survival of 2-3 years. ${ }^{8,13}$ No proven effective pharmacological therapy has yet been found. ${ }^{3}$ Some prognostic factors have already been described, which may have implications for potential therapy, particularly when to refer for lung transplant, which up until now has been the only therapy with 
demonstrated survival benefit. ${ }^{14,15}$ Recently, Pirfenidone, an oral antifibrotic and anti-inflammatory drug, has been approved by EMEA (European Medicines Agency) for the treatment of IPF.

Our aim was to describe the clinical presentation and the course of IPF patients who have been evaluated in recent years in our Interstitial Lung Diseases (ILD) outpatient clinic and analyze factors associated with survival and the clinical course.

\section{Methods}

Patients diagnosed with IPF, who attended an ILD outpatient clinic in Hospital de São João, a tertiary reference center in Oporto, Portugal, were identified. IPF diagnosis was obtained through an UIP compatible histology by surgical lung biopsy in 25 patients (30.9\%). In 56 patients (69.1\%), IPF diagnosis was based on ATS/ERS criteria (according to 2002 consensus). ${ }^{2}$ Whenever atypical signs were found on HRCT or other atypical characteristics that could raise diagnostic issues, patients were sent for surgical lung biopsy. Patients whose UIP pattern could be explained by other diseases (connective tissue diseases, hypersensitivity pneumonitis, drug lung toxicity and other ILDs whose final stage is fibrosis), were excluded.

Medical records were retrospectively analyzed. Patients were characterized clinically, physiologically and by radiological findings, at the time of diagnosis.

Rest and exercise physiological assessments (spirometry, lung diffusing capacity for carbon monoxide - DLCO, Total Lung Capacity - TLC, six-minute walk test - 6MWT and cardiopulmonary exercise test) were measured according to ERS and ATS recommendations ${ }^{16-20}$ and results were expressed as percentages of the normal predicted values. Physiological parameters obtained after any medication that could probably modify the course of the disease were excluded.

Some patients were not able to perform the exercise capacity evaluation due to a high degree of disability at diagnosis.

All patients performed HRCT scan at diagnosis. As this was a retrospective study, some of the HRCT images were not available for analysis, although all the reports were accessible. For imaging characterization, chest HRCT images were analyzed by two radiologists and the extent of the disease was calculated as a fibrotic score ${ }^{21}$ the same used to validate the Composite Physiologic Index (CPI).

Bronchoalveolar lavage (BAL) was performed on an outpatient basis. At the time of BAL, no symptoms or signs suggestive of respiratory infection or exacerbation of the disease were observed. The performance and processing of BAL was carried out according to guidelines of the ERS Task Group on BAL. ${ }^{22}$ Total and differential cell count was classified according to the values proposed by ERS Task Group on BAL (lymphocytosis $>15 \%$, neutrophilia $>3 \%$, eosinophilia $>0.5 \%) .^{22}$

Open lung biopsy was performed under general anesthesia and the most common approach used was a limited anterolateral thoracotomy via a $4 \pm 10 \mathrm{~cm}$ submammary incision, which allowed access to segments of different lobes in order to obtain multiple biopsy specimens. Open lung biopsy was always performed through thoracotomy. The site of the biopsy was decided on the basis of the HRCT scan. Biopsy samples were observed and evaluated independently by two pathologists.

To evaluate the occurrence of pulmonary hypertension, all patients performed echocardiography. Only the patients referred for lung transplantation underwent right heart catheterization.

Clinical course was classified as slow progression, rapid progression and acute exacerbation (AE-IPF). Rapid progression was differentiated from slow progression by a shorter duration of symptoms at diagnosis ( $<6$ months) and a more rapid clinical deterioration. ${ }^{10} \mathrm{AE}-\mathrm{IPF}$ was defined as a sudden worsening of respiratory symptoms with hypoxemia and appearance of new radiological infiltrates without an identifiable cause. ${ }^{11}$

Patients included had IPF diagnoses established between 2000 and 2010. They were followed during the course of the disease, until death or lung transplant.

\section{Statistical analysis}

Kolmogorov-Smirnov test was used to check for normality of the distributions in all continuous variables. Medians for covariates and percentages of factors were computed and baseline differences in patients with slow versus rapid progression were assessed through U Mann-Whitney, Chi square or Fischer exact test, as appropriate.

Median survival was estimated using Kaplan-Meier survival curves. Patients were censored at the time of death or lung transplant. Follow-up was stopped after 48 months, to increase statistical power of the study. To identify the strength of prognostic factors, Hazard Ratios (and their respective $95 \%$ confidence intervals) were computed using univariate Cox regression models.

All analyses were performed using SPSS ${ }^{\circledR}$ software v. 18. A $p$-value $<0.05$ was considered significant.

\section{Results}

\section{Patients' characterization at diagnosis}

Eighty-one patients were included, 56 (69.1\%) men and 25 (30.9\%) women. Mean age at diagnosis was $63.8 \pm 10.2$ years old. Two patients (2.5\%) had familial IPF. A smoking history was found in $51.9 \%$ (27.5\% current and $72.5 \%$ former smokers) accounting for a mean of 37.5 pack-years. The main symptom at presentation was dyspnea (96.3\%), followed by cough (77.9\%). Median time between beginning of symptoms and time of diagnosis was 12 months.

Restrictive physiology and reduced lung diffusion capacity were the main functional abnormalities (Table 1) as well as exercise capacity impairment. 6MWT was taken into consideration for 40 patients, with a mean (Standard deviation SD) distance of 369.6 (149.4) meters and a mean (SD) lowest oxygen saturation of 81.5 (8.1) \%. Cardiopulmonary Exercise Test was looked at for only 15 patients with a mean (SD) peak oxygen consumption of $66.6(18.4) \%$.

HRCT scan fibrotic score was measured in 42 patients. Mean (SD) fibrotic score was 10.8 (2.3). 
Table 1 Physiological assessment in IPF patients at time of diagnosis.

\begin{tabular}{llr}
\hline Physiological assessment at diagnosis & Mean & \multicolumn{1}{c}{ SD } \\
\hline FVC $(n=71)$ & 74.8 & \pm 20.2 \\
FEV1 $(n=71)$ & 80.8 & \pm 19.3 \\
FEV1/FVC $(n=69)$ & 85.6 & \pm 7.8 \\
TLC $(n=65)$ & 70.8 & \pm 15.7 \\
$\mathrm{DLCO}(n=57)$ & 45.8 & \pm 16.4 \\
$\mathrm{PaO}_{2}(n=62)$ & 71.3 & \pm 14.5 \\
$\mathrm{PaCO}_{2}(n=56)$ & 40.1 & \pm 4.8 \\
\hline
\end{tabular}

The prevalence of emphysema in this IPF cohort was 26.4\% (14/53 HRCT available for reevaluation). Patients with emphysema were younger -61.8 vs. 69.9 years $(p=0.042)$, had a higher smoking load - 28.3 vs. 10.7 pack-years $(p=0.035)$, lower FEV1/FVC - 79 vs. $86.9 \%(p=0.001)$ and more severely compromised diffusion capacity (DLCO) -36.8 vs. $49.9 \%(p=0.016)$.

BAL was performed in 56 patients at the time of diagnosis, with neutrophilia (mean $=10.8, \mathrm{SD}=2.3$ ) in $52(92.9 \%)$ patients, eosinophilia (mean $=5.1, S D=5.0$ ) in $48(85.7 \%)$ patients and mild lymphocytosis being detected in 14 (25\%) patients (mean $=12, \mathrm{SD}=7.8$ ).

\section{Clinical course}

Regarding therapeutic approach, ATS/ERS statement was followed and, if there were no contraindications, low doses of corticosteroids (86.4\%) and immunosuppressive drugs (65.4\%), preferably azatioprine or alternatively, cyclophosphamide were used. After the publication of IFIGENIA trial ${ }^{23}$ in $2005, \mathrm{~N}$-acetylcysteine $(1800 \mathrm{mg} /$ day) was added to this regimen (51.9\%). Up until now, Pirfenidone has not been available in Portugal. Moreover, when the included IPF patients were diagnosed, Pirfenidone was still not approved by EMEA and there was no Portuguese center participating in any clinical trial using this drug.

Since a protocol was established in 2007 with Hospital Juan Canalejo (Coruña) and Hospital Santa Marta (Lisbon), patients under 65 years have been considered to lung transplantation. As this series includes patients diagnosed since 2000 , there is still only a small percentage of transplanted patients. To be precise, 9 patients $(7.4 \%)$ were selected for lung transplantation and single lung transplant was performed in 6 ( 2 patients were excluded because of infection by Aspergillus fumigatus). Another patient is on waiting list.

Clinical course $(n=76)$ was mainly slowly progressive (72.3\%). In 10 patients (13.2\%), IPF had a rapid progression and $11(14.5 \%)$ patients had an AE-IPF during the course of their disease.

IPF's rapid progression (Table 2) was found to be associated to a higher functional impairment at diagnosis, namely

Table 2 Baseline factors and its association with clinical course (rapid versus slow progression).

\begin{tabular}{|c|c|c|c|}
\hline & \multicolumn{3}{|c|}{$N(\%)$ or mean \pm SD } \\
\hline & Slow progressors $(n=55)$ & Rapid progressors $(n=10)$ & $p$ \\
\hline Age & $69.2 \pm 9.8$ & $69.4 \pm 11.2$ & 0.954 \\
\hline \multicolumn{4}{|l|}{ Sex } \\
\hline$\sigma^{7}$ & $37(67.3 \%)$ & $8(80 \%)$ & \multirow[t]{2}{*}{0.346} \\
\hline ㅇ & $18(32.7 \%)$ & $2(20 \%)$ & \\
\hline \multicolumn{4}{|l|}{ Smoke history } \\
\hline No & $21(40.4 \%)$ & $8(88.9 \%)$ & \multirow[t]{2}{*}{0.020} \\
\hline Yes & $31(59.6 \%)$ & $1(11.1 \%)$ & \\
\hline FVC & $76.2 \pm 21.0$ & $57.5 \pm 10.9$ & 0.003 \\
\hline TLC & $72.2 \pm 16.1$ & $59.8 \pm 10.7$ & 0.032 \\
\hline DLCO & $44.6 \pm 14.7$ & $38.1 \pm 12.5$ & 0.204 \\
\hline $\mathrm{PaO}_{2}$ & $73.6 \pm 16.6$ & $63.3 \pm 11.4$ & 0.055 \\
\hline 6MWT distance $(\mathrm{m})$ & $377.2 \pm 131.2$ & $265.2 \pm 226.4$ & 0.318 \\
\hline $6 \mathrm{MWT}$ Min $\mathrm{SatO}_{2}$ & $81.7 \pm 7.9$ & $77.3 \pm 8.6$ & 0.242 \\
\hline Fibrotic score & $11.2 \pm 2.3$ & $11.0 \pm 2.2$ & 0.192 \\
\hline \multicolumn{4}{|c|}{ Pulmonary hypertension } \\
\hline No & $36(87.8 \%)$ & $5(62.5 \%)$ & \multirow[t]{2}{*}{0.110} \\
\hline Yes & $5(12.2 \%)$ & $3(37.5 \%)$ & \\
\hline \% Lymph & $11.5 \pm 7.5$ & $12.9 \pm 5.2$ & 0.241 \\
\hline \% Neutroph & $10.5 \pm 9.8$ & $12.6 \pm 8.2$ & 0.272 \\
\hline \% Eosinoph & $5.9 \pm 5.3$ & $4.2 \pm 5.3$ & 0.154 \\
\hline
\end{tabular}

\% Lymph - percentage of lymphocytes at BAL differential count; \% Neutroph - percentage of neutrophils at BAL differential count; \% Eosinoph - percentage of eosinophils at BAL differential count. Significant results are presented in bold. 
with FVC $(p=0.003)$ and TLC $(p=0.032)$. A smoking history was associated with a slowly progressive clinical course $(p=0.020)$.

Most IPF patients $(69.6 \%)$ died of causes directly related to the disease - respiratory failure, while in 13 patients (23.2\%), the cause of death was due to other causes. Four patients $(7.1 \%)$ died of post-lung transplant complications.

AE-IPF occurred in 11 patients. Among them, 6 (54.5\%) died during the episode and 2 were submitted to lung transplantation, dying due to post-transplant complications.

\section{Survival}

Median survival was 36 months (Fig. 1). Twenty-five patients were still alive at the time of evaluation.

Factors found to be associated with poorer survival, in univariate analysis (Table 3 ), were lower levels of FVC $(p=0.000)$, TLC $(p=0.001), 6 \mathrm{MWT}$ distance $(p=0.014)$ and rest $\mathrm{PaO}_{2}(p=0.008)$, as well as higher $\mathrm{BAL}$ neutrophil count $(p=0.039)$.

It was not possible to identify cut-points for each prognostic factor because of the lack of statistical power (small sample size).

Table 3 Survival Prognostic Factors of IPF patients.

\begin{tabular}{|c|c|c|}
\hline & HR (CI 95\%) unadjusted & $p$ \\
\hline Age & $1.01(0.98-1.04)$ & 0.505 \\
\hline \multicolumn{3}{|l|}{ Sex } \\
\hline Men & Ref & \\
\hline Women & $0.78(0.40-1.51)$ & 0.451 \\
\hline \multicolumn{3}{|l|}{ Smoke history } \\
\hline No & Ref & \\
\hline Yes & $0.60(0.33-1.09)$ & 0.092 \\
\hline FVC & $0.96(0.94-0.98)$ & 0.000 \\
\hline TLC & $0.96(0.94-0.98)$ & 0.001 \\
\hline DLCO & $0.98(0.96-1.01)$ & 0.187 \\
\hline $\mathrm{DLCO}<40$ & $1.97(0.96-4.01)$ & 0.063 \\
\hline $\mathrm{DLCO} \geq 40$ & Ref & \\
\hline $\mathrm{PaO}_{2}$ & $0.97(0.94-0.99)$ & 0.008 \\
\hline \multicolumn{3}{|l|}{$6 M W T$} \\
\hline Meters & $1.00(0.99-1.00)$ & 0.014 \\
\hline \multicolumn{3}{|l|}{$6 M W T$} \\
\hline Lowest $\mathrm{SatO}_{2}$ & $1.00(0.95-1.05)$ & 0.894 \\
\hline $\mathrm{SatO}_{2} \leq 88$ & $1.63(0.38-6.98)$ & 0.512 \\
\hline $\mathrm{SatO}_{2}>88$ & Ref & \\
\hline $\mathrm{VO}_{2}$ & $0.97(0.91-1.03)$ & 0.244 \\
\hline HRCT fibrotic score & $1.08(0.90-1.29)$ & 0.407 \\
\hline \multicolumn{3}{|c|}{ Pulmonary hypertension } \\
\hline No & Ref & \\
\hline Yes & $1.10(0.39-3.15)$ & 0.854 \\
\hline Lymph \% & $1.00(0.95-1.05)$ & 0.999 \\
\hline Neutroph \% & $1.03(1.00-1.06)$ & 0.039 \\
\hline Eosinoph \% & $0.97(0.90-1.05)$ & 0.398 \\
\hline
\end{tabular}

HR - Hazard ratio.
Testing cut-points of the baseline prognostic factors described in the last consensus document ${ }^{3}$ (DLCO $<40 \%$ of predicted; desaturation $\leq 88 \%$ during $6 \mathrm{MWT}$; presence of pulmonary hypertension), had no significant associations in this sample, although estimates follow the expected direction.

No significant difference in survival rates was found between IPF patients with and without emphysema.

Median survival was 41 months in slow progressors and 9 months in rapid progressors (Fig. 1).

Among slow progressors, lower levels of FVC $(p=0.001)$, TLC $(p=0.012)$ and 6MWT distance $(p=0.026)$ were associated to a reduced survival.

No prognostic factors were found in rapid progressors (reduced statistical power due to a small number of patients).

\section{Discussion}

The evaluation of this cohort of IPF patients from the north of Portugal showed the usual features that characterize this disease, in terms of clinical, functional, radiologic parameters and outcome. Although some baseline prognostic factors were associated with overall survival in this series, the main issue is related with the sort of clinical course, more exactly the distinction between slow progression and rapid progression since their outcome and survival are significantly different.

Mean age at diagnosis was consistent with literature, ${ }^{3,24}$ as well as the higher prevalence of males. Familial IPF may be undervalued. In fact, some patients report family deaths from unspecified respiratory diseases. Cigarette smoking is strongly associated with IPF, namely in those patients with heavy smoking history, more precisely more than 20 pack years. ${ }^{25,26}$ In this study, the proportion of smokers and former smokers was lower than expected, as was the case in other series. ${ }^{27,28}$ However, in the 15 patients aged under 60 years old, $80 \%$ had a history of cigarette smoking, so we can speculate that excluding ageing, smoking history could have been a significant risk factor for IPF in this sample. Twelve months was the median time between beginning of symptoms and diagnosis. Kim et al. ${ }^{1}$ reported a period of 6 months to 2 years of symptoms preceding diagnosis. In fact, not only patients tend to attribute the initial breathlessness to ageing, but also primary care physicians tend to focus the clinical investigation on cardiac diseases and other respiratory diseases such as COPD, based on their higher prevalence. However, in this cohort of patients there was an increasing number of patients referred by general practice over the last few years, which could be related to the widespread use of CT scans.

Recently, a new syndrome has been described - Combined Pulmonary Fibrosis and Emphysema (CPFE), resulting from the association of IPF and emphysema. ${ }^{29,30}$ The percentage of CPFE found in this cohort is in line with other publications. $^{30}$ In this study, some previously described distinctive features were observed, namely a stronger association with smoking, lower levels of FEV1/FVC and a higher compromise on diffusion capacity (DLCO). However, some authors describe a negative impact on prognosis when IPF is associated with emphysema. ${ }^{30}$ This negative impact is 

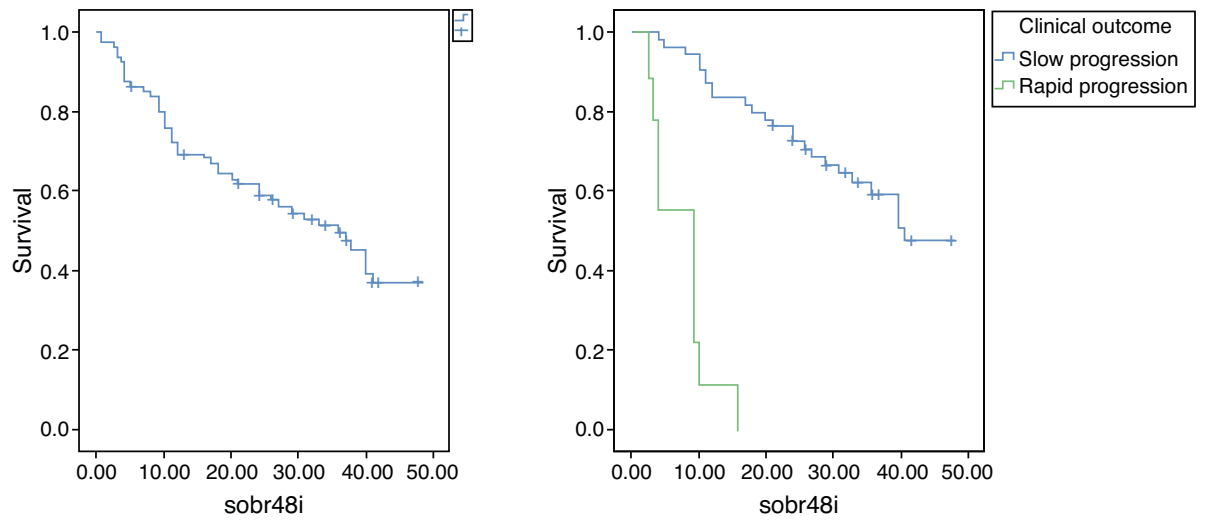

Figure 1 Kaplan-Meier survival curves for all IPF patients (left) and for slow and rapid progressors (right) - months.

strongly associated to pulmonary hypertension. ${ }^{30}$ In this study we did not find a significant difference in survival or in the occurrence of pulmonary hypertension.

Lymphocytosis was detected in 14 patients (25\%). They presented a mild lymphocytosis (mean of $22.8 \%$ ) and no exposure to suspected agents was detected. Also, in $50 \%$ of these patients a lung biopsy was performed to rule out other differential diagnoses. Moreover no difference on survival was found between patients with or without BAL lymphocytosis.

Clinical course cannot yet be predicted accurately. In this sample, $13.2 \%$ of patients experienced an accelerated decline, already described in literature. ${ }^{10}$ However, criteria for classification of IPF progression are not well established. The definition of rapid progressors is based on a time-period between symptoms and diagnosis of less than 6 months, associated with an accelerated decline. , $^{10}$ The difference in survival between low and rapid IPF progressors is remarkable (41 and 9 months, respectively). Although this subject is still not clearly understood, these groups must represent different phenotypes in IPF. At a univariate analysis, lower levels of FVC and TLC were associated to a rapidly progressive disease. Non-smokers were also associated to rapid progression. This was already described in other studies, also with a better survival in current smokers; ${ }^{31}$ and there is no clear explanation for this. Some data suggest that cigarette smoke inhibits lung fibroblast proliferation as well as chemotaxis, and may that way impair lung repair after lung injury. ${ }^{32} \mathrm{~A}$ recent study contradicts this fact, showing a better outcome for non-smokers, and assuming that the better outcome previously reported for smokers was compatible with a healthy smoker lead-time effect (reflecting a less severe disease at presentation). ${ }^{33}$

AE-IPF has been a main focus of interest. The results of this study are in line with publications on this subject, both in terms of incidence and mortality. In fact, incidence of AE-IPF is $10-15 \%$ of all IPF patients, according to two large randomized clinical trials 34,35 and its mortality is high, ranging between 50 and 100\%. ${ }^{12,36-38}$ Excluding patients who received lung transplant, this study registered an in-hospital mortality of $66.7 \%$ in AE-IPF. There have been several attempts to identify acute exacerbations predictors, without success. ${ }^{38}$ In fact, the occurrence of AE-IPF does not appear to be related to the severity of pulmonary function impairment. ${ }^{38}$ It was the same for this study, no factor was identified which could predict its occurrence.

Median survival in this sample is in line with other studies. ${ }^{39,40}$ Predictors of mortality in IPF have been divided in baseline and dynamic predictors. ${ }^{41}$ In fact, prognosis in IPF should involve the integration of baseline and longitudinal data. This study only meant to evaluate baseline predictors. Factors associated with a poorer survival in this cohort at univariate analysis are related to higher functional decline (FVC, TLC), worse oxygenation $\left(\mathrm{PaO}_{2}\right)$, reduced tolerance to exercise (distance in 6MWT) and higher neutrophil count on BAL.

When reviewing the literature, what is remarkable is the great variability in prognostic factors. There are several reasons for this, such as series with a small number of patients or the inclusion of patients with co-morbidities which act as confounding factors. Most studies have different diagnostic and therapeutic approaches relating to the patients included; although when we consider the lack of effective pharmacologic therapeutics, this latter factor is hardly likely to affect the accuracy of the results. Moreover this cohort of patients was divided according to their phenotypes, since the prognostic factors must be adapted to each of the three types of outcome as their outstanding different clinical course. The prognostic factors concerned, that is lower levels of FVC, TLC and 6MWT distance, are all significantly associated with the low progression subgroup. The lack of any association with rapid progressors may be explained by the fact that the sample size was too small to give a significant result.

Several studies have tended to ascribe prognostic values to baseline pulmonary function tests, giving the impression that a higher functional decline is significantly associated with a reduced survival. The factors concerned are usually FVC $^{27,42-44}$ and TLC, ${ }^{42,44}$ with higher evidence supporting the first parameter. The association of DLCO with reduced survival rates is a consistent finding across the literature. ${ }^{42-45}$ It is a fact that lower diffusion capacity reflects a greater extent of fibrosis and increased severity of the disease. However, in this sample there was no prognostic impact. There are some studies which show baseline $\mathrm{PaO}_{2}$ at rest as a predictor of mortality, ${ }^{8,27,43,46}$ although there are also 
some contradictory results. ${ }^{44,47}$ Higher degrees of hypoxemia occur in more advanced stages of the disease but whether this can be considered as a prognostic factor or not, is yet to be established. There are studies which have ascribed prognostic significance in relation to survival rates to 6MWT parameters, ${ }^{48-51}$ either linked to the walking distance or to desaturation peak, but these results are underestimated due to lack of standardization and reproductability of this test.

BAL neutrophilia has been associated with severity as in other diffuse lung disease such as sarcoidosis. ${ }^{52}$ There is also some evidence that a higher level of neutrophilia may be associated with lower survival rates. ${ }^{53}$ Although neutrophilia is usually described as a baseline prognostic factor in univariate analysis, multivariate analysis does not confirm this association according to studies published in peer-review literature. ${ }^{54,55}$

Pulmonary hypertension should have a multifactorial pathogenesis for IPF. Several studies point out pulmonary hypertension to be a predictor of mortality, ${ }^{56,57}$ but usually in longitudinal studies. In our sample, pulmonary hypertension at baseline did not act as a prognostic factor.

Some coefficients ${ }^{21,58}$ have been proposed in order to combine different parameters. For instance, the Composite Physiologic Index, which includes FVC, FEV1, DLCO and fibrosis extension on HRCT scan, has been successfully tested at baseline and longitudinal studies. ${ }^{21,59}$ This could be a way to predict outcome more accurately and to provide a more precise timing of the progression of the disease.

In conclusion, IPF is inevitably associated with a poor prognosis. However, different phenotypes seem to be emerging, based on the striking differences in clinical course. A more accurate prediction of the outcome at the moment of diagnosis would improve patient management, particularly in the time to reference to lung transplant, which is the only therapy with demonstrated survival benefit.

\section{Conflicts of interest}

The authors have no conflicts of interest to declare.

\section{Acknowledgments}

Special thanks to Carla Damas, responsible for the Lung Transplant outpatient clinic of Hospital de São João, for the near cooperation on IPF patients' referral to transplant, when indicated.

\section{References}

1. Kim DS, Collard HR, King Jr TE. Classification and natural history of idiopathic interstitial pneumonias. Proc Am Thorac Soc. 2006;3:285-92.

2. American Thoracic Society, European Respiratory Society. American Thoracic Society/European Respiratory Society International Multidisciplinary Consensus Classification of the Idiopathic Interstitial Pneumonias. Am J Respir Crit Care Med. 2002;165:277-304.

3. Raghu G, Collard HR, Egan JJ, Martinez FJ, Behr J, Brown KK, et al. An official ATS/ERS/JRS/ALAT statement: idiopathic pulmonary fibrosis: evidence-based guidelines for diagnosis and management. Am J Respir Crit Care Med. 2011;183: 788-824.

4. Fernández Pérez ER, Daniels CE, Schroeder DR, St Sauver J, Hartman TE, Bartholmai BJ, et al. Incidence, prevalence and clinical course of idiopathic pulmonary fibrosis. Chest. 2010;137:129-37.

5. Frankel SK, Schwarz MI. Update in idiopathic pulmonary fibrosis. Curr Opin Pulm Med. 2009;15:463-9.

6. Visscher DW, Myers JL. Histologic spectrum of idiopathic interstitial pneumonias. Proc Am Thorac Soc. 2006;3:322-9.

7. Wells AU, Hirani N. Interstitial lung disease guideline: the British Thoracic Society in collaboration with the Thoracic Society of Australia and New Zealand and the Irish Thoracic Society. Thorax. 2008;63 Suppl V:v1-58.

8. Turner-Warwick M, Burrows B, Johnson A. Crytogenic fibrosing alveolitis: clinical features and their influence on survival. Thorax. 1980;35:171-80.

9. Schwartz DA, Helmers RA, Galvin JR, Van Fossen DS, Frees KL, Dayton CS, et al. Determinants of survival in idiopathic pulmonary fibrosis. Am J Respir Crit Care Med. 1994;149 2 Pt $1: 450-4$.

10. Selman M, Carrillo G, Estrada A, Mejia M, Becerril C, Cisneros $J$, et al. Accelerated variant of idiopathic pulmonary fibrosis: clinical behavior and gene expression pattern. PLOS ONE. 2007;2:e482.

11. Collard HR, Moore BB, Flaherty KR, Brown KK, Kaner RJ, King Jr TE, et al. Acute exacerbations of idiopathic pulmonary fibrosis. Am J Respir Crit Care Med. 2007;176:636-43.

12. Song JW, Hong SB, Lim CM, Koh Y, Kim DS. Acute exacerbation of idiopathic pulmonary fibrosis: incidence, risk factors and outcome. Eur Respir J. 2011;37:356-63.

13. Collard HR, King Jr TE, Bartelson BB, Vourlekis JS, Schwarz MI, Brown KK. Changes in clinical and physiologic variables predict survival in idiopathic pulmonary fibrosis. Am J Respir Crit Care Med. 2003;168:538-42.

14. Nathan SD. Lung transplantation: disease-specific considerations for referral. Chest. 2005;127:1006-16.

15. Trulock EP, Edwards LB, Taylor DO, Boucek MM, Keck BM, Hertz MI. Registry of the International Society for Heart and Lung Transplantation: twenty-third official adult lung and heartlung transplantation report - 2006. J Heart Lung Transplant. 2006;25:880-92.

16. Miller MR, Hankinson J, Brusasco V, Burgos F, Casaburi R, Coates $A$, et al. Standardisation of spirometry. Eur Respir J. 2005;26:319-38.

17. Wanger J, Clausen JL, Coates A, Pedersen OF, Brusasco V, Burgos $F$, et al. Standardisation of the measurement of lung volumes. Eur Respir J. 2005;26:511-22.

18. MacIntyre N, Crapo RO, Viegi G, Johnson DC, van der Grinten $\mathrm{CP}$, Brusasco V, et al. Standardisation of the single-breath determination of carbon monoxide uptake in the lung. Eur Respir J. 2005;26:720-35.

19. ATS statement: guidelines for the six-minute walk test. Am J Respir Crit Care Med. 2002;166:111-7.

20. ERS Task Force on Standardization of Clinical Exercise Testing. Clinical exercise testing with reference to lung diseases: indications, standardization and interpretation strategies. Eur Respir J. 1997; 10:2662-89.

21. Wells AU, Desai SR, Rubens MB, Goh NS, Cramer D, Nicholson AG, et al. Idiopathic Pulmonary Fibrosis. A Composite Physiologic Index derived from disease extent observed by computed tomography. Am J Respir Crit Care Med. 2003;167: 962-9.

22. Klech $\mathrm{H}$, Hutter $\mathrm{C}$. Clinical guidelines and indications for bronchoalveolar lavage (BAL): report of the European Society of Pneumology Task Force on BAL. Eur Respir J. 1990;3: 937-76. 
23. Demedts M, Behr J, Buhl R, Costabel U, Dekhuijzen R, Jansen $\mathrm{HM}$, et al. High-dose acetylcysteine in idiopathic pulmonary fibrosis. N Engl J Med. 2005;353:2229-42.

24. Dempsey OJ, Kerr KM, Gomersall L, Remmen H, Currie GP. Idiopathic pulmonary fibrosis: an update. Q J Med. 2006;99: 643-54.

25. Baumgartner KB, Samet JM, Stidley CA, Colby TV, Waldron JA. Cigarette smoking: a risk factor for idiopathic pulmonary fibrosis. Am J Respir Crit Care Med. 1997;155:242-8.

26. Hanley ME, King Jr TE, Schwartz MI, Watters LC, Shen AS, Cherniack RM. The impact of smoking on mechanical properties of the lungs in idiopathic pulmonary fibrosis and sarcoidosis. Am Rev Respir Dis. 1991;144:1102-6.

27. Rubin AS, Moreira JS, Porto NS, Irion KL, Moreira RF, Scheidt B. Fatores prognósticos em fibrose pulmonar idiopática. J Pneumol. 2000;26:227-34.

28. Maheshwari U, Gupta D, Aggarwal AN, Jindal SK. Spectrum and diagnosis of idiopathic pulmonary fibrosis. Indian J Chest Allied Sci. 2004;46:23-6.

29. Cottin V, Nunes H, Brillet PY, Delaval P, Devouassoux G, Tillie-Leblond I, et al. Combined pulmonary fibrosis and emphysema: a distinct underrecognised entity. Eur Respir J. 2005;26: 586-93.

30. Mejía M, Carrillo G, Rojas-Serrano J, Estrada A, Suárez T, Alonso $D$, et al. Idiopathic pulmonary fibrosis and emphysema: decreased survival associated with severe pulmonary arterial hypertension. Chest. 2009;136:10-5.

31. King Jr TE, Tooze JA, Schwartz MI, Brown KR, Cherniak RM. Predicting survival in idiopathic pulmonary fibrosis: scoring system and survival model. Am J Respir Crit Care Med. 2001;164:1171-81.

32. Nakamura $Y$, Romberger DJ, Tate L, Ertl RF, Kawamoto $M$, Adachi $Y$, et al. Cigarette smoke inhibits lung fibroblast proliferation and chemotaxis. Am J Respir Crit Care Med. 1995;151: 1497-503.

33. Antoniou KM, Hansell DM, Rubens MB, Marten K, Desai SR, Siafakas NM, et al. Idiopathic pulmonary fibrosis Outcome in relation to smoking status. Am J Respir Crit Care Med. 2008;177:190-4.

34. Azuma A, Nukiwa T, Tsuboi E, Suga M, Abe S, Nakata $K$, et al. Double-blind, placebo-controlled trial of pirfenidone in patients with idiopathic pulmonary fibrosis. Am J Respir Crit Care Med. 2005;171:1040-7.

35. Martinez FJ, Safrin S, Weycker D, Starko KM, Bradford WZ, King Jr TE, et al. The clinical course of patients with idiopathic pulmonary fibrosis. Ann Intern Med. 2005;142 Pt I: 963-7.

36. Ambrosini V, Cancellieri A, Chilosi M, Zompatori M, Trisolini $\mathrm{R}$, Saragoni $\mathrm{L}$, et al. Acute exacerbation of idiopathic pulmonary fibrosis: report of a series. Eur Respir J. 2003;22: 821-6.

37. Melo N, Damas C, Souto Moura C, Morais A. Acute exacerbation of idiopathic pulmonary fibrosis. Rev Port Pneumol. 2009;15:305-12.

38. Kim DS, Park JH, Park BK, Lee JS, Nicholson AG, Colby T. Acute exacerbation of idiopathic pulmonary fibrosis: frequency and clinical features. Eur Respir J. 2006;27:143-50.

39. Flaherty KR, Toews GB, Travis WD, Colby TV, Kazerooni EA, Gross $\mathrm{BH}$, et al. Clinical significance of histological classification of idiopathic interstitial pneumonia. Eur Respir J. 2002;19: 275-83.

40. Rudd RM, Prescott RJ, Chalmers JC, Johnston IDA, Fibrosing Alveolitis Subcommittee of the Research Committee of the British Thoracic Society. British Thoracic Society Study on cryptogenic fibrosing alveolitis: response to treatment and survival. Thorax. 2007;62:62-6.
41. Carbone R, Balleari E, Grosso M, Montanaro F, Bottino G, Ghio R. Predictors of mortality of idiopathic pulmonary fibrosis. Eur Rev Med Pharmacol Sci. 2008;12:97-104.

42. Bjoraker JA, Ryu JH, Edwin MK, Myers JL, Tazelaar HD, Schroeder DR, et al. Prognostic significance of histopathologic subsets in idiopathic pulmonary fibrosis. Am J Respir Crit Care Med. 1998;157:199-203.

43. Stephan S, de Castro Pereira CA, Coletta EM, Ferreira RG, Otta JS, Nery LE. Oxygen desaturation during a 4-minute step test: predicting survival in idiopathic pulmonary fibrosis. Sarcoidosis Vasc Diffuse Lung Dis. 2007;24:70-6.

44. Erbes R, Schaberg T, Loddenkemper R. Lung function tests in patients with idiopathic pulmonary fibrosis. Are they helpful for predicting outcome? Chest. 1997;111:51-7.

45. Jegal Y, Kim DS, Shim TS, Lim CM, Do Lee S, Koh Y, et al. Physiology is a stronger predictor of survival than pathology in fibrotic interstitial pneumonia. Am J Respir Crit Care Med. 2005;171:639-44.

46. Hiwatari N, Shimura S, Sasaki T, Aikawa T, Ando Y, Ishihara $\mathrm{H}$, et al. Prognosis of idiopathic pulmonary fibrosis in patients with mucous hypersecretion. Am Rev Respir Dis. 1991;143: 182-5.

47. Miki K, Maekura R, Hiraga T, Okuda Y, Okamoto T, Hirotani $A$, et al. Impairments and prognostic factors for survival in patients with pulmonary idiopathic pulmonary fibrosis. Respir Med. 2003;97:482-90.

48. Flaherty KR, Andrei AC, Murray S, Fraley C, Colby TV, Travis WD, et al. Idiopathic pulmonary fibrosis: prognostic value of changes in physiology and six-minute-walk test. Am J Respir Crit Care Med. 2006;174:803-9.

49. Lama VN, Flaherty KR, Toews GB, Colby TV, Travis WD, Long Q, et al. Prognostic value of desaturation during a 6-minute-walk test in idiopathic interstitial pneumonia. Am J Respir Crit Care Med. 2003;168:1084-90.

50. Lederer DJ, Arcasoy SM, Wilt JS, D’Ovidio F, Sonnet JR, Kawut SM. Six-minute-walk distance predicts waiting list survival in idiopathic pulmonary fibrosis. Am J Respir Crit Care Med. 2006;174:659-64.

51. Caminati A, Bianchi A, Cassandro R, Mirenda MR, Harari S. Walking distance on 6-MWT is a prognostic factor in idiopathic pulmonary fibrosis. Respir Med. 2009;103: 117-23.

52. Drent M, Jacobs JA, de Vries J, Lamers RJ, Liem IH, Wouters EF. Does the cellular bronchoalveolar lavage fluid profile reflect the severity of sarcoidosis? Eur Resp J. 1999;13: 1338-44.

53. Kinder BW, Brown KK, Schwartz MI, Ix JH, Kervitsky A, King Jr TE. Baseline BAL neutrophilia predicts early mortality in idiopathic pulmonary fibrosis. Chest. 2008;133:226-32.

54. Tabuena RP, Nagai S, Tsutsumi T, Handa T, Minoru T, Mikunyia $\mathrm{T}$, et al. Cell profiles of bronchoalveolar lavage fluid as prognosticators of idiopathic pulmonary fibrosis/usual interstitial pneumonia among Japanese patients. Respiration. 2005;72:490-8.

55. Veeraraghavan S, Latsi PI, Wells AU, Pantelidis P, Nicholson AG, Colby TV, et al. BAL findings in idiopathic nonspecific interstitial pneumonia and usual interstitial pneumonia. Eur Respir J. 2003;22:239-44.

56. Lettieri CJ, Nathan SD, Barnett SD, Ahmad S, Shorr AF. Prevalence and outcomes of pulmonary arterial hypertension in advanced idiopathic pulmonary fibrosis. Chest. 2006;129: 746-52.

57. Nadrous HF, Pellikka PA, Krowka MJ, Swanson KL, Chaowalit $\mathrm{N}$, Decker PA, et al. Pulmonary hypertension in patients with idiopathic pulmonary fibrosis. Chest. 2005;128: 2393-9. 
58. Du Bois RM, Weycker D, Albera C, Bradford WZ, Costabel U, Kartashov A, et al. Ascertainment if individual risk of mortality for patients with idiopathic pulmonary fibrosis. Am J Respir Crit Care Med. 2011;184:459-66.
59. Schmidt SL, Nambiar AM, Tayob N, Sundaram B, Han MK, Gross $\mathrm{BH}$, et al. Pulmonary function measures predict mortality differently in IPF versus combined pulmonary fibrosis and emphysema. Eur Respir J. 2011;38:176-83. 